Fixed Point Theory, 20(2019), No. 2, 635-648

DOI: $10.24193 /$ fpt-ro.2019.2.42

http://www.math.ubbcluj.ro/ nodeacj/sfptcj.html

\title{
FIXED POINT RESULTS UNDER GENERALIZED c-DISTANCE WITH APPLICATION TO NONLINEAR FOURTH-ORDER DIFFERENTIAL EQUATION
}

\author{
GHASEM SOLEIMANI RAD*,1 ${ }^{*}$ HAMIDREZA RAHIMI** AND CALOGERO VETRO*** \\ *Young Researchers and Elite club, West Tehran Branch \\ Islamic Azad University, Tehran, Iran \\ E-mail: gha.soleimani.sci@iauctb.ac.ir; gh.soleimani2008@gmail.com \\ ** Department of Mathematics, Faculty of Science, Central Tehran Branch \\ Islamic Azad University, P.O. Box 13185/768, Tehran, Iran \\ E-mail: rahimi@iauctb.ac.ir \\ *** Department of Mathematics and Computer Science, University of Palermo \\ Via Archirafi 34, 90123, Palermo, Italy \\ E-mail: calogero.vetro@unipa.it
}

\begin{abstract}
We consider the notion of generalized $c$-distance in the setting of ordered cone $b$-metric spaces and obtain some new fixed point results. Our results provide a more general statement, under which can be unified some theorems of the existing literature. In particular, we refer to the results of Sintunavarat et al. [W. Sintunavarat, Y.J. Cho, P. Kumam, Common fixed point theorems for $c$ distance in ordered cone metric spaces, Comput. Math. Appl. 62 (2011) 1969-1978]. Some examples and an application to nonlinear fourth-order differential equation are given to support the theory.

Key Words and Phrases: Partially ordered set, ordered cone $b$-metric space, generalized $c$ distance, fixed point.
\end{abstract}

2010 Mathematics Subject Classification: 47H10, 54H25.

Acknowledgement. The authors are grateful to the editorial board and referees for their accurate reading and their helpful suggestions. Also, the first author is thankful to the Young Researchers and Elite club of West Tehran Branch of Islamic Azad University.

\section{REFERENCES}

[1] I. Altun, B. Damnjanović, D. Djorić, Fixed point and common fixed point theorems on ordered cone metric spaces, Appl. Math. Lett., 23(2010), 310-316.

[2] I.A. Bakhtin, The contraction mapping principle in quasimetric spaces, Func. Anal. Gos. Ped. Inst. Unianowsk., 30(1989), 26-37.

[3] B. Bao, S. Xu, L. Shi, V. Čojbašić Rajić, Fixed point theorems on generalized c-distance in ordered cone b-metric spaces, Int. J. Nonlinear Anal. Appl., 6(2015), no. 1, 9-22.

\footnotetext{
${ }^{1}$ Corresponding author.
} 
[4] Y.J. Cho, R. Saadati, S.H. Wang, Common fixed point theorems on generalized distance in ordered cone metric spaces, Comput. Math. Appl., 61(2011), 1254-1260.

[5] A.S. Ćvetković, M.P. Stanić, S. Dimitrijević, S. Simić, Common fixed point theorems for four mappings on cone metric type space, Fixed Point Theory Appl., 589725(2011), 15 pages.

[6] S. Czerwik, Contraction mappings in b-metric spaces, Acta Math. Inform. Univ. Ostrava, 1(1993), no. 1, 5-11.

[7] K. Deimling, Nonlinear Functional Analysis, Springer-Verlag, 1985.

[8] M. Djordević, D. Dorić, Z. Kadelburg, S. Radenović, D. Spasić, Fixed point results under cdistance in tvs-cone metric spaces, Fixed Point Theory Appl., 29(2011), 9 pages.

[9] L.G. Huang, X. Zhang, Cone metric spaces and fixed point theorems of contractive mappings, J. Math. Anal. Appl., 332(2007), 1467-1475.

[10] N. Hussain, R. Saadati, R.P. Agrawal, On the topology and wt-distance on metric type spaces, Fixed Point Theory Appl., 88(2014), 14 pages.

[11] N. Hussain, M.H. Shah, KKM mapping in cone b-metric spaces, Comput. Math. Appl., 62(2011), 1677-1684.

[12] M. Jleli, V. C̆ojbašić Rajić, B. Samet, C. Vetro, Fixed point theorems on ordered metric spaces and applications to nonlinear elastic beam equations, J. Fixed Point Theory Appl., 12(2012), 175-192.

[13] O. Kada, T. Suzuki, W. Takahashi, Nonconvex minimization theorems and fixed point theorems in complete metric spaces, Math. Japon., 44(1996), 381-391.

[14] H. Rahimi, G. Soleimani Rad, Fixed point theorems under c-distance in ordered cone metric space, Int. J. Industrial Math., 6(2014), no. 2, 97-105.

[15] H. Rahimi, G. Soleimani Rad, Common fixed-point theorems and c-distance in ordered cone metric spaces, Ukrainian Math. J., 65(2014), no. 12, 1845-1861.

[16] H. Rahimi, G. Soleimani Rad, P. Kumam, A generalized distance in a cone metric space and new common fixed point results, U.P.B. Sci. Bull. (Series A)., 77(2015), no. 2, 195-206.

[17] W. Sintunavarat, Y.J. Cho, P. Kumam, Common fixed point theorems for c-distance in ordered cone metric spaces, Comput. Math. Appl., 62(2011), 1969-1978.

[18] P.P. Zabrejko, K-metric and K-normed linear spaces: survey, Collect. Math., 48(1997), 825859.

[19] S. Wang, B. Guo, Distance in cone metric spaces and common fixed point theorems, Appl. Math. Lett., 24(2011), 1735-1739.

Received: November 16, 2016; Accepted: February 2, 2018. 